\title{
PROFIL BERPIKIR ALJABAR SISWA SMP DALAM MEMECAHKAN MASALAH MATEMATIKA KONTEKSTUAL DITINJAU DARI KEMAMPUAN MATEMATIKA
}

\author{
Siti Laiyinun Yusrina \\ Pendidikan Matematika, Fakultas Matematika dan Ilmu Pengetahuan Alam, Universitas Negeri Surabaya \\ Email: sitiyusrina@mhs.unesa.ac.id
}

\author{
Masriyah \\ Pendidikan Matematika, Fakultas Matematika dan Ilmu Pengetahuan Alam, Universitas Negeri Surabaya \\ Email: masriyah@unesa.ac.id
}

\begin{abstract}
Abstrak
Aljabar merupakan salah satu konsep penting dalam matematika dan mulai diajarkan di kelas VII SMP. Salah satu cara untuk mengetahui kemampuan berpikir dan bernalar siswa secara aljabar yaitu dengan berpikir aljabar. Berpikir aljabar merupakan suatu aktivitas mental yang terdiri atas generalisasi, abstraksi, berpikir dinamis, pemodelan, berpikir analitis, dan organisasi. Sarana yang dapat digunakan untuk menggali berpikir aljabar siswa adalah pemecahan masalah. Masalah yang digunakan dalam penelitian ini adalah masalah matematika kontekstual. Berpikir aljabar pada setiap siswa dalam memecahkan masalah matematika kontekstual berbeda-beda berdasarkan tingkat kemampuan matematika. Tujuan penelitian ini untuk mendeskripsikan profil berpikir aljabar siswa SMP dalam memecahkan masalah matematika kontekstual ditinjau dari kemampuan matematika. Penelitian ini menggunakan pendekatan kualitatif dengan metode pengumpulan data melalui tes dan wawancara. Subjek penelitian ini yaitu satu siswa dengan kemampuan matematika tinggi, satu siswa dengan kemampuan matematika sedang, dan satu siswa dengan kemampuan matematika rendah. Hasil penelitian ini menunjukkan berpikir aljabar siswa dengan kemampuan matematika tinggi dalam memecahkan masalah matematika kontekstual terdiri atas generalisasi, abstraksi, berpikir dinamis, pemodelan, berpikir analitis, dan organisasi. Berpikir aljabar siswa dengan kemampuan matematika sedang dalam memecahkan masalah matematika kontekstual terdiri atas generalisasi, abstraksi, berpikir dinamis, pemodelan, berpikir analitis, dan organisasi. Berpikir aljabar siswa dengan kemampuan matematika rendah dalam memecahkan masalah matematika kontekstual terdiri atas generalisasi, berpikir dinamis, dan organisasi.
\end{abstract}

Kata Kunci: berpikir aljabar, pemecahan masalah, masalah matematika kontekstual, kemampuan matematika.

\begin{abstract}
Algebra is one of the important concepts in mathematics and began to be taught in class VII of junior high school. One way to find out students' thinking and reasoning abilities algebraically is to algebraic thinking. Algebraic thinking is a mental activity consisting of generalization, abstraction, dynamic thinking, modeling, analytic thinking, and organization. The means that can be used to explore students' algebraic thinking is problem solving. The problem used in this research is contextual mathematical problems. Algebraic thinking in each student in solving contextual mathematical problems varies based on the level of mathematical abilities. The purpose of this research is to describe the algebraic thinking's profile of junior high school students in solving contextual mathematical problems based on mathematical abilities. This research uses a qualitative approach with methods of collecting data through tests and interviews. The subjects of this research were one student with high mathematical abilities, one student with medium mathematical abilities, and one student with low mathematical abilities. The results of this research indicate algebraic thinking of student with high mathematical abilities, consists of generalization, abstraction, dynamic thinking, modeling, analytic thinking, and organization. Algebraic thinking of student with medium mathematical abilities, consists of generalization, abstraction, dynamic thinking, modeling, analytic thinking, and organization. Algebraic thinking of student with low mathematical abilities, consists of generalization, dynamic thinking, and organization.
\end{abstract}

Keywords: algebraic thinking, problem solving, contextual mathematical problems, mathematical abilities. 


\section{PENDAHULUAN}

Salah satu konsep penting yang diajarkan dalam matematika di sekolah adalah aljabar. Konsep aljabar mulai diajarkan pada tingkat Sekolah Menengah Pertama (SMP), yaitu pada kelas VII berdasarkan Kompetensi Inti dan Kompetensi Dasar Matematika Kurikulum 2013 edisi revisi tahun 2017. Oleh karena itu, siswa dituntut memiliki penguasaan konsep aljabar dengan baik dan mengaplikasikannya untuk memecahkan suatu permasalahan.

Akan tetapi fakta di lapangan menunjukkan hal yang berbeda. Aljabar yang seharusnya penting justru memberikan masalah tersendiri bagi siswa. Siswa di sekolah menengah umumnya mengalami kesulitan dalam mempelajarinya. Febriansyah (2014) mengungkapkan bahwa penyebab kesulitan belajar siswa SMP adalah siswa kesulitan mengidentifikasi variabel, koefisien, dan kesulitan menentukan penyelesaian soal yang dihadapi.

Berdasarkan temuan dari beberapa penelitian lain juga menyebutkan bahwa kesulitan siswa dalam mempelajari konsep aljabar disebabkan perbedaan yang signifikan antara aritmetika yang diajarkan dengan aljabar (Rivera, 2006:306). Hal tersebut tentunya perlu diperhatikan, khususnya terhadap berpikir aljabar siswa tingkat menengah pertama (SMP) sebagai alat untuk menyelesaikan soal atau masalah matematika yang menggunakan pendekatan aljabar. Siswa akan mengalami kesulitan dalam memahami fakta, konsep, dan aturan atau prosedur penyelesaian aljabar yang lebih kompleks bila kemampuan ini tidak dimiliki dengan baik oleh siswa. Sehingga, penting untuk mengetahui kemampuan berpikir dan bernalar secara aljabar siswa dalam menyelesaikan suatu masalah matematika.

Lew (2004:93) menjelaskan bahwa "success in algebra depends on at least six kinds of mathematical thinking abilities as follows: generalization, abstraction, analytic thinking, dynamic thinking, modeling, and organization." Menurut Lew, keberhasilan siswa dalam berpikir aljabar bergantung pada enam jenis berpikir matematis, yaitu generalisasi, abstraksi, berpikir analitis, berpikir dinamis, pemodelan dan organisasi. Sejalan dengan Lew, Walle (2008) mengungkapkan bahwa berpikir aljabar adalah aktivitas mental yang terdiri dari berbagai kegiatan berpikir di antaranya melakukan generalisasi dari pengalaman dengan bilangan dan perhitungan, serta memformulasikan ide-ide dengan penggunaan simbol yang berguna dan mengeksplorasi konsep-konsep dari pola dan fungsi.

Salah satu sarana yang dapat digunakan untuk menggali munculnya berpikir aljabar pada siswa yaitu menggunakan pemecahan masalah. Siswa diberikan suatu permasalahan yang melibatkan konsep aljabar, kemudian siswa diminta untuk dapat memecahkan masalah tersebut. Hal ini sesuai dengan pendapat Bednarz (1992) yang mengungkapkan bahwa pemecahan masalah memiliki peranan penting untuk perkembangan aljabar.

Masalah yang menantang dapat memberikan kesempatan bagi siswa untuk menggunakan segala kemampuan yang dimiliki termasuk berpikir aljabar. Hal ini selaras dengan pernyataan Suharnan (2005:279) bahwa kebanyakan aktivitas pemecahan masalah atau pembentukan konsep melibatkan proses berpikir. Dengan melibatkan siswa dalam pemecahan suatu permasalahan diharapkan berpikir aljabar dan karakteristiknya muncul, sehingga dapat digali, diketahui, dan dipahami oleh guru.

Anggo (2011) berpendapat bahwa penggunaan konteks dalam pembelajaran matematika menjadikan konsepkonsep abstrak dapat dipahami berdasarkan pemikiran yang dibangun dari situasi realistik tertentu yang sudah dikenal dengan baik oleh siswa. Hal tersebut juga berlaku pada pembelajaran matematika materi aljabar. Konsep aljabar akan lebih mudah diterima dan dipahami oleh siswa bila konsep tersebut dipadukan atau dikaitakan dengan masalah kehidupan sehari-hari. Dengan demikian, masalah yang digunakan dalam penelitian ini merupakan masalah matematika kontekstual.

Berpikir aljabar pada setiap siswa dalam memecahkan masalah matematika kontekstual berbeda-beda berdasarkan tingkat kemampuan matematika. Kemampuan matematika terdiri atas tiga kategori yaitu kemampuan matematika tinggi, kemampuan matematika sedang, dan kemampuan matematika rendah. Isroil, dkk (2017) menemukan bahwa terdapat perbedaan profil berpikir siswa yang memiliki kemampuan matematika tinggi, sedang, dan rendah dalam memecahkan masalah matematika. Lebih lanjut, hasil penelitian Lingga dan Sari (2013) menunjukkan bahwa kemampuan berpikir aljabar mempengaruhi kemampuan dalam memecahkan masalah matematika. Siswa yang memiliki kemampuan berpikir aljabar dengan baik cenderung lebih mahir dalam memecahkan masalah matematika, dan siswa yang tidak memiliki kemampuan berpikir aljabar dengan baik cenderung mengalami kesulitan dalam memecahkan masalah matematika. Hal ini menunjukkan berpikir aljabar dalam memecahkan masalah matematika dipengaruhi oleh kemampuan matematika.

Berdasarkan uraian tersebut, tujuan penelitian yaitu mendeskripsikan profil berpikir aljabar siswa SMP dalam memecahkan masalah matematika kontekstual ditinjau dari kemampuan matematika.

\section{METODE}

Pendekatan yang digunakan dalam penelitian ini merupakan pendekatan kualitatif. Sedangkan jenis penelitian yang digunakan merupaan penelitian deskriptif. Instrumen yang digunakan dalam penelitian ini ada dua 
jenis, yaitu instrumen utama adalah peneliti sendiri, dan instrumen pendukung yang meliputi tes kemampuan matematika (TKM), tes pemecahan masalah matematika kontekstual (TPMMK), dan pedoman wawancara. Pengumpulan data dalam penelitian ini menggunakan metode tes (TKM dan TPMMK) dan wawancara.

Penelitian ini dilaksanakan pada 37 siswa kelas VIII-C di SMP Negeri 4 Sidoarjo semester genap tahun pelajaran 2018/2019. Dari 37 siswa, dipilih tiga siswa untuk menjadi subjek penelitian, yaitu satu siswa dengan kemampuan matematika tinggi, satu siswa dengan kemampuan matematika sedang, dan satu siswa dengan kemampuan matematika rendah. Penentuan kategori kemampuan matematika siswa berdasarkan skor hasil TKM dengan rentang masing-masing kategori sebagai berikut.

Tabel 1. Kategori Kemampuan Matematika

\begin{tabular}{|c|c|c|}
\hline \multicolumn{3}{|c|}{ Kemampuan Matematika } \\
\hline Tinggi & Rendah & Sedang \\
\hline $80<x \leqslant 100$ & $65<x \leqslant 80$ & $0 \leqslant x \leqslant 65$ \\
\hline \multicolumn{3}{|c|}{ Ket $: x$ adalah skor hasil TKM yang diperoleh siswa }
\end{tabular}

Selain itu, dalam memilih subjek, peneliti juga memperhatikan jenis kelamin yang sama dan kemampuan komunikasi yang baik.

Tiga subjek yang telah dipilih diberikan kode yang mewakili masing-masing subjek penelitian sebagai berikut.

Tabel 2. Kode Subjek Penelitian

\begin{tabular}{|c|c|c|c|}
\hline $\begin{array}{c}\text { Kode } \\
\text { Nama }\end{array}$ & Skor TKM & $\begin{array}{c}\text { Kategori } \\
\text { Kemampuan } \\
\text { Matematika }\end{array}$ & $\begin{array}{c}\text { Kode } \\
\text { Subjek }\end{array}$ \\
\hline DP & 96 & Tinggi & SKT \\
\hline SPQ & 72 & Sedang & SKS \\
\hline FRMY & 40 & Rendah & SKR \\
\hline
\end{tabular}

Prosedur penelitian secara garis besar disajikan dalam bagan dibawah ini.

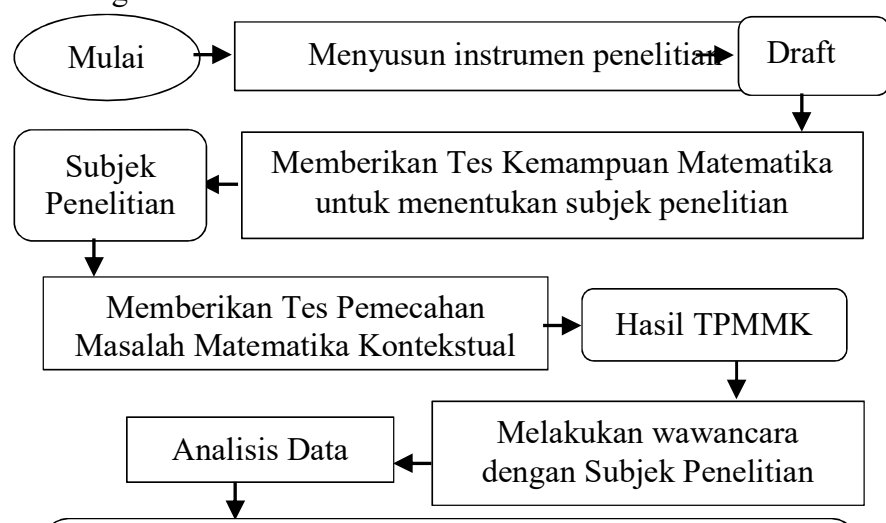

Profil Berpikir Aljabar Siswa dalam Memecahkan Masalah Matematika Kontekstual Ditinjau dari Kemampuan Matematika

Teknik analisis data dalam penelitian ini meliputi reduksi data, penyajian data dan penarikan kesimpulan.
Analisis data hasil TPMMK dan wawancara mengacu pada indikator berpikir aljabar berikut.

Tabel 3. Indikator Berpikir Aljabar

\begin{tabular}{|l|l|}
\hline Berpikir Aljabar & \multicolumn{1}{|c|}{ Indikator Berpikir Aljabar } \\
\hline Generalisasi & $\begin{array}{l}\text { Mengidentifikasi hubungan antar } \\
\text { objek dan menemukan pola atau } \\
\text { bentuk umum dari sekumpulan } \\
\text { objek yang diberikan. }\end{array}$ \\
\hline Abstraksi & $\begin{array}{l}\text { Menggunakan simbol berupa huruf } \\
\text { atau gambar untuk } \\
\text { merepresentasikan variabel sebagai } \\
\text { sesuatu yang belum diketahui } \\
\text { nilainya berdasarkan generalisasi. }\end{array}$ \\
\hline Berpikir Dinamis & $\begin{array}{l}\text { Memecahkan masalah dengan } \\
\text { menggunakan berbagai cara. }\end{array}$ \\
\hline Pemodelan & $\begin{array}{l}\text { Merepresentasikan situasi dalam } \\
\text { masalah menjadi model } \\
\text { matematika. }\end{array}$ \\
\hline Berpikir Analitis & $\begin{array}{l}\text { Menyelesaikan masalah dengan } \\
\text { menggunakan persamaan untuk } \\
\text { menentukan nilai dari variabel } \\
\text { sebagai sesuatu yang belum } \\
\text { diketahui nilainya. }\end{array}$ \\
\hline Organisasi & $\begin{array}{l}\text { Memilih dan menyusun data } \\
\text { dengan membuat tabel, atau } \\
\text { gambar, atau diagram, atau kata- } \\
\text { kata, yang dapat menggambarkan } \\
\text { situasi masalah dan hubungan } \\
\text { antara kondisi masalah secara } \\
\text { keseluruhan. }\end{array}$ \\
\hline
\end{tabular}

\section{HASIL DAN PEMBAHASAN}

Berdasarkan analisis data berpikir aljabar subjek dengan kemampuan matematika tinggi, kemampuan matematika sedang, dan kemampuan matematika rendah dalam memecahkan masalah matematika kontekstual, diperoleh deskripsi profil berpikir aljabar siswa SMP dalam memecahkan masalah matematika kontekstual ditinjau dari kemampuan matematika, dengan pemabahasan sebagai berikut.

1. Hasil Analisis Data Subjek dengan Kemampuan Matematika Tinggi dalam Memecahkan Masalah Matematika Kontekstual

Berikut ini pembahasan hasil analisis data berpikir aljabar subjek SKT dalam memecahkan masalah matematika kontekstual berdasarkan indikator berpikir aljabar yang meliputi generalisasi, abstraksi, berpikir dinamis, pemodelan, berpikir analitis dan organisasi.

Berdasarkan hasil analisis data pada masalah poin A, subjek memahami maksud soal dengan baik dan mengutarakan kembali menggunakan bahasanya sendiri. Langkah pertama yang dilakukan subjek dalam 
menentukan pemecahan masalah, yaitu mengidentifikasi hubungan antar objek (urutan meter, banyak paving block hitam, dan banyak paving block putih) dengan cara mendaftar dalam tabel dan menemukan pola dari sekumpulan objek, subjek menyebutkan bahwa paving block hitam dari bentuk sebelumnya ke bentuk selanjutnya selalu bertambah 1 buah dan paving block putih dari bentuk sebelumnya ke bentuk selanjutnya selalu bertambah 2 buah. Selanjutnya subjek menggunakan pola yang telah ditemukan untuk menentukan suku berikutnya, jika paving block hitam sebanyak 10 buah maka banyak paving block putih adalah 26 buah. Selain itu subjek juga memecahkan masalah poin A menggunakan cara/alternatif lain, yaitu menggambar susunan paving block seperti ilustrasi desain dalam masalah. Subjek menjelaskan cara menentukan banyak paving block putih menggunakan gambar, langkah pertama subjek menggambar paving block hitam secara horizontal sebanyak yang diketahui, kemudian menggambar paving block putih di atas dan di bawah gambar paving block hitam dengan jumlah yang sama, lalu menggambar 3 buah paving block putih secara vertikal di ujung kanan dan ujung kiri. Sehingga dalam memecahkan masalah poin A, subjek memenuhi indikator berpikir aljabar (1) mengidentifikasi hubungan antar objek dan menemukan pola dari sekumpulan objek yang diberikan (generalisasi), (2) merepresentasikan situasi dalam masalah dengan cara menyusun informasi dalam tabel untuk menentukan pemecahan masalah (organisasi), (3) memecahkan masalah (menentukan suku berikutnya) dengan menggunakan berbagai cara (berpikir dinamis).

Berdasarkan hasil analisis data pada masalah poin B, subjek memahami maksud soal dengan baik dan mengutarakan kembali menggunakan bahasanya sendiri. Subjek menjelaskan maksud $n$ sebagai simbol yang mewakili banyak paving block hitam. Langkah pertama yang dilakukan subjek dalam memecahkan masalah, yaitu mengetahui banyak paving block hitam, kemudian banyak paving block hitam dikalikan 2 dan ditambah 6. Sehingga diperoleh pemecahan jika diketahui banyak paving block hitam adalah $n$ buah maka banyak paving block putih adalah $2 n+6$ buah. Subjek dalam memecahkan masalah poin B juga memberikan cara/alternatif lain, yaitu mendaftar informasi yang diketahui dalam bentuk tabel dan melihat pola yang ditemukan, dari kegiatan tersebut diperoleh bentuk umum banyak paving block putih. Sehingga dalam memecahkan masalah poin B, subjek memenuhi indikator berpikir aljabar (1) menggunakan simbol berupa huruf untuk merepresentasikan variabel sebagai sesuatu yang belum diketahui nilainya berdasarkan generalisasi (abstraksi), (2) memecahkan masalah (menentukan bentuk umum banyak paving block putih) dengan menggunakan berbagai cara (berpikir dinamis), (3) merepresentasikan situasi dalam masalah dengan cara menyusun informasi dalam tabel untuk menentukan pemecahan masalah (organisasi).

Berdasarkan hasil analisis data pada masalah poin C, subjek memahami maksud soal dengan baik dan mengutarakan kembali menggunakan bahasanya sendiri. Langkah pertama yang dilakukan subjek dalam memecahkan masalah, yaitu membuat sebuah model matematika dalam bentuk persamaan yang mengaitkan informasi dari soal (diketahui banyak paving block putih 150 buah) dan hasil pemecahan masalah yang diperoleh sebelumnya (bentuk umum banyak paving block putih $2 n+6$ ) sebagai representasi situasi dalam masalah poin $\mathrm{C}$. Bentuk persamaan yang dibuat subjek adalah $2 n+6=150$. Selanjutnya subjek menyelesaikan persamaan tersebut untuk menentukan nilai $n$ yang mewakili banyak paving block hitam, dari kegiatan ini subjek memperoleh hasil $n=72$ buah, hasil yang diperoleh merupakan penyelesaian dari masalah poin $\mathrm{C}$. Sehingga dalam memecahkan masalah poin $C$, subjek memenuhi indikator berpikir aljabar (1) merepresentasikan situasi dalam masalah menjadi model matematika (pemodelan), (2) menyelesaikan masalah dengan menggunakan persamaan untuk menentukan nilai dari variabel sebagai sesuatu yang belum diketahui nilainya (berpikir analitis). Hal tersebut sesuai dengan hasil penelitian Isroil, dkk (2017) bahwa dalam tahap merancang rencana penyelesaian, subjek dengan kemampuan matematika tinggi membuat model matematika sesuai dengan informasi yang ada pada soal dan dalam tahap melaksanakan rencana penyelesaian subjek menggunakan pengetahuan terdahulu tentang operasi hitung bilangan dan aljabar dengan benar, serta hasil penyelesaian yang diperoleh benar.

Berdasarkan uraian di atas, diketahui bahwa SKT memecahkan masalah TPMMK dengan benar, serta dalam memecahkan masalah seluruh enam aktivitas berpikir aljabar muncul, hal ini sesuai dengan hasil penelitian Maulidiah (2016) bahwa dalam memecahkan masalah matematika subjek dengan kemampuan matematika tinggi melakukan setiap tahapan pemecahan masalah, dan indikator berpikir aljabar selalu muncul dalam pemecahan masalah.

2. Hasil Analisis Data Berpikir Aljabar Subjek dengan Kemampuan Matematika Sedang dalam Memecahkan Masalah Matematika Kontestual

Berikut ini pembahasan hasil analisis data berpikir aljabar SKS dalam memecahkan masalah matematika kontekstual berdasarkan indikator berpikir aljabar yang 
meliputi generalisasi, abstraksi, berpikir dinamis, pemodelan, berpikir analitis dan organisasi.

Berdasarkan hasil analisis data pada masalah poin A, subjek dapat memahami maksud soal dengan baik dan mengutarakan kembali menggunakan bahasanya sendiri. Langkah pertama yang dilakukan subjek dalam memecahkan masalah poin $\mathrm{A}$, yaitu mengidentifikasi hubungan antar objek (urutan meter, banyak paving block hitam, dan banyak paving block putih) dengan cara mendaftar dalam tabel dan menemukan pola dari sekumpulan objek tersebut. Subjek menyebutkan jumlah paving block hitam selalu bertambah 1 buah setiap meternya dan jumlah paving block putih selalu bertambah 2 buah setiap meternya. Subjek memperoleh hasil pemecahan jika banyak paving block hitam 10 buah, maka banyak paving block putih adalah 26 buah. Subjek juga memecahkan masalah poin A menggunakan cara/alternatif lain yaitu menggambar susunan paving block seperti ilustrasi desain dalam masalah. Sehingga dalam memecahkan masalah poin A, subjek memenuhi indikator berpikir aljabar (1) mengidentifikasi hubungan antar objek dan menemukan pola dari sekumpulan objek yang diberikan (generalisasi), (2) merepresentasikan situasi dalam masalah dengan cara menyusun informasi dalam tabel untuk menentukan pemecahan masalah (organisasi), (3) memecahkan masalah (menentukan suku berikutnya) dengan menggunakan berbagai cara (berpikir dinamis).

Berdasarkan hasil analisis data pada masalah poin B, subjek memahami maksud soal dengan baik dan mengutarakan kembali menggunakan bahasanya sendiri. Subjek menjelaskan maksud $n$ sebagai simbol yang mewakili jumlah paving block hitam. Langkah pertama yang dilakukan subjek dalam memecahkan masalah poin B, yaitu menggunakan pola yang telah ditemukan sebelumnya pada masalah poin $\mathrm{A}$, kemudian mendaftar objek-objek yang berkaitan (urutan meter, banyak paving block hitam, dan banyak paving block putih) dalam bentuk tabel, sehingga diperoleh bentuk umum dari banyak paving block putih adalah 2 kali banyak paving block hitam ditambah 6 paving block putih. Jika paving block hitam sebanyak $n$ buah, maka paving block putih sebanyak $2 n+6$ buah. Subjek juga melakukan peninjauan kembali terhadap temuannya untuk memastikan bahwa temuannya merupakan hasil yang benar, bahwa bentuk umum banyak paving block putih adalah $2 n+6$. Subjek membuat pemisalan $n=3$ (banyak paving block hitam sebanyak 3 buah) maka banyak paving block putih adalah $2(3)+6=12$ buah. Sehingga dalam memecahkan masalah poin $B$, subjek memenuhi indikator berpikir aljabar (1) menggunakan simbol berupa huruf untuk merepresentasikan variabel sebagai sesuatu yang belum diketahui nilainya berdasarkan generalisasi (abstraksi), (2) merepresentasikan situasi dalam masalah dengan cara menyusun informasi dalam tabel untuk menentukan pemecahan masalah (organisasi).

Berdasarkan hasil analisis data pada masalah poin C, subjek memahami maksud soal dengan baik dan mengutarakan kembali menggunakan bahasanya sendiri. Langkah pertama yang dilakukan subjek dalam memecahkan masalah poin $\mathrm{C}$, yaitu mengaitkan bentuk umum banyak paving block putih yang telah ditemukan sebelumnya pada masalah poin B $(2 n+6$ atau banyak paving block putih adalah 2 kali banyak paving block hitam ditambah 6 paving block putih) dengan informasi yang diperoleh dari soal (diketahui banyak paving block putih 150 buah). Selanjutnya subjek menerapkan operasi terbalik (strategi bekerja mundur) untuk memperoleh hasil akhir sebagai pemecahan masalah. Subjek menyebutkan karena banyak paving block putih adalah 2 kali banyak paving block hitam ditambah 6 paving block putih dan diketahui banyak paving block putih adalah 150 buah, maka untuk menentukan banyak paving block hitam adalah (150-6): $2=72$, jadi banyak paving block hitam yang diperoleh 72 buah. Hal ini sesuai dengan pendapat Lew (2004) bahwa strategi bekerja mundur juga merupakan contoh khas dari berpikir analitis, yaitu proses untuk menerapkan operasi terbalik dari operasi yang diterapkan dalam kondisi suatu masalah untuk menentukan hasil akhir.

Sehingga dalam memecahkan masalah poin $C$, subjek memenuhi indikator berpikir aljabar (1) merepresentasikan situasi dalam masalah menjadi model matematika (pemodelan), (2) menyelesaikan masalah dengan menggunakan persamaan untuk menentukan nilai dari variabel sebagai sesuatu yang belum diketahui nilainya (berpikir analitis). Hal tersebut sesuai dengan hasil penelitian Isroil, dkk (2017) bahwa subjek dengan kemampuan matematika sedang dalam merancang rencana penyelesaian masalah membuat model matematika sesuai dengan informasi yang diperoleh dari soal, dan dalam melaksanakan rencana penyelesaian masalah menggunakan pengetahuan terdahulu tentang operasi hitung bilangan dan aljabar dengan benar, serta hasil penyelesaian yang diperoleh benar.

Berdasarkan uraian di atas, diketahui bahwa SKS dapat memecahkan masalah TPMMK dengan benar, serta dalam memecahkan masalah seluruh enam aktivitas berpikir aljabar muncul, hal ini sesuai dengan hasil penelitian Maulidiah (2016) bahwa dalam memecahkan masalah matematika subjek dengan kemampuan matematika sedang melakukan setiap 
tahapan pemecahan masalah dan indikator berpikir aljabar muncul dalam pemecahan masalah.

3. Hasil Analisis Data Subjek dengan Kemampuan Matematika Rendah dalam Memecahkan Masalah Matematika Kontekstual

Berikut ini pembahasan hasil analisis data berpikir aljabar SKR dalam memecahkan masalah matematika kontekstual berdasarkan indikator bepikir aljabar yang meliputi generalisasi, abstraksi, berpikir dinamis, pemodelan, berpikir analitis, dan organisasi.

Berdasarkan hasil analisis data pada masalah poin A, subjek memahami maksud soal dengan baik dan mengutarakan kembali menggunakan bahasanya sendiri. Langkah pertama yang dilakukan subjek dalam memecahkan masalah poin A, yaitu mengidentifikasi hubungan antar objek (urutan meter, banyak paving block hitam, dan paving block putih) dengan cara mendaftar informasi yang diperoleh dalam bentuk tabel, kemudian menemukan pola dari sekumpulan objek tersebut, dari tabel yang telah dibuat subjek menemukan jika banyak paving block hitam 10 buah maka banyak paving block putih 26 buah. Selain itu subjek juga memecahkan masalah poin $\mathrm{A}$ menggunakan cara/alternatif lain, yaitu menggambar susunan paving block seperti ilustrasi desain dalam masalah dengan banyak paving block hitam 10 buah dan banyak paving block putih 26 buah. Sehingga dalam memecahkan masalah poin A, subjek memenuhi indikator berpikir aljabar (1) mengidentifikasi hubungan antar objek dan menemukan pola dari sekumpulan objek yang diberkan (generalisasi), (2) merepresentasikan situasi dalam masalah dengan cara menyusun informasi dalam tabel untuk menentukan penyelesaian masalah (organisasi), (3) memecahkan masalah (menentukan suku berikutnya) dengan menggunakan berbagai cara (berpikir dinamis).

Berdasarkan hasil analisis data pada masalah poin B, subjek mengutarakan kembali maksud soal namun tidak dapat memahaminya dengan benar. Subjek tidak dapat menjelaskan makna penggunaan $\operatorname{simbol} n$ sebagai representasi banyak paving block hitam. Hal tersebut mengakibatkan subjek tidak dapat menentukan banyak paving block putih berdasarkan generalisasi yang merupakan indikator aktivitas abstraksi, sehingga tidak diperoleh pemecahan masalah dengan benar. Hal ini dapat diketahui pada saat wawancara, subjek mengatakan bahwa ia mengalami kebingungan dalam menentukan penyelesaian masalah, karena subjek tidak mengetahui makna simbol $n$. Dengan demikian, tidak ada indikator berpikir aljabar yang terpenuhi oleh subjek pada pemecahan masalah poin B. Hal ini sesuai dengan hasil penelitian Maulidiah (2016) bahwa subjek dengan kemampuan matematika rendah merasa kesulitan/tidak dapat menentukan bentuk umum (bentuk ke-n) dari masalah yang diberikan.

Berdasarkan hasil analisis data pada masalah poin C, subjek memahami maksud soal dan mengutarakan kembali menggunakan bahasanya sendiri. Namun subjek tidak dapat menentukan penyelesaian masalah poin $\mathrm{C}$ dengan benar, hal ini disebabkan karena subjek tidak melakukan aktivitas abstraksi pada masalah poin B yang merupakan kunci dalam menyelesaikan masalah poin C. Sehingga dalam memecahkan masalah poin $\mathrm{C}$, tidak ada indikator berpikir aljabar yang terpenuhi. Hal ini sesuai dengan hasil penelitian Isroil, dkk (2017) bahwa subjek dengan kemampuan matematika rendah dalam merancang rencana penyelesaian membuat model matematika yang kurang sesuai dengan informasi yang diterima, hal ini disebabkan karena subjek tidak melakukan aktivitas abstraksi dengan baik, dan dalam melaksanakan rencana penyelesaian menggunakan pengetahuan terdahulu tentang operasi hitung bilangan, namun melakukan kesalahan sehingga hasil penyelesaian masalah yang diperoleh tidak benar.

\section{PENUTUP}

\section{Simpulan}

Berdasarkan hasil analisis data dan pembahasan yang telah diuraikan, maka dapat ditarik kesimpulan "Profil Berpikir Aljabar Siswa SMP dalam memecahkan Masalah Matematika Kontekstual Ditinjau dari Kemampuan Matematika" sebagai berikut.

Profil Berpikir Aljabar Siswa SMP dengan Kemampuan Matematika Tinggi dalam Memecahkan Masalah Matematika Kontekstual

Pada aktivitas generalisasi, langkah pertama yang dilakukan siswa dalam memecahkan masalah, yaitu mengidentifikasi hubungan antar objek dengan cara mendaftar dalam tabel dan menemukan pola dari sekumpulan objek tersebut, kemudian menyebutkan pola yang telah ditemukan. Selanjutnya, siswa menggunakan pola yang telah ditemukan untuk menentukan suku berikutnya. Selain itu, siswa juga mengidentifikasi hubungan antar objek dengan menggunakan gambar dan menemukan pola dari sekumpulan objek tersebut, kemudian menggunakan pola yang telah ditemukan untuk menentukan suku berikutnya.

Pada aktivitas abstraksi, siswa menjelaskan penggunaan simbol berupa huruf sebagai representasi variabel. Langkah pertama yang dilakukan siswa dalam memecahkan masalah yaitu menggunakan informasi yang telah ditemukan sebelumnya dari aktivitas generalisasi, kemudian siswa menentukan bentuk umum. Selanjutnya 
merepresentasikan bentuk umum yang telah ditemukan dengan menggunakan simbol.

Pada aktivitas berpikir dinamis, siswa memberikan cara/alternatif lain dalam menentukan pemecahan masalah dengan menggunakan tabel dan gambar.

Pada aktivitas pemodelan, siswa membuat sebuah model matematika dalam bentuk persamaan yang mengaitkan informasi dari soal dengan hasil pemecahan masalah yang diperoleh sebelumnya sebagai representasi situasi yang baru.

Pada aktivitas berpikir analitis, siswa menyelesaikan persamaan yang telah dibuat sebelumnya secara bertahap untuk menentukan nilai dari variabel sebagai hasil akhir pemecahan masalah.

Pada aktivitas organisasi, siswa menyusun informasi penting yang diperoleh dari masalah dalam bentuk tabel untuk menentukan pemecahan masalah.

Profil Berpikir Aljabar Siswa SMP dengan Kemampuan Matematika Sedang dalam Memecahkan Masalah Matematika Kontekstual

Pada aktivitas generalisasi, langkah pertama yang dilakukan siswa dalam memecahkan masalah, yaitu mengidentifikasi hubungan antar objek dengan cara mendaftar dalam tabel dan menemukan pola dari sekumpulan objek tersebut, kemudian menyebutkan pola yang telah ditemukan. Selanjutnya, siswa menggunakan pola yang telah ditemukan untuk menentukan suku berikutnya. Selain itu, siswa juga mengidentifikasi hubungan antar objek dengan menggunakan gambar dan menemukan pola dari sekumpulan objek tersebut, kemudian menggunakan pola yang telah ditemukan untuk menentukan suku berikutnya.

Pada aktivitas abstraksi, siswa menjelaskan penggunaan simbol berupa huruf sebagai representasi variabel. Langkah pertama yang dilakukan siswa dalam memecahkan masalah yaitu menggunakan informasi yang telah ditemukan sebelumnya dari aktivitas generalisasi, dengan cara mendaftar objek-objek yang berkaitan dalam bentuk tabel sehingga diperoleh bentuk umum, selanjutnya merepresentasikan bentuk umum yang telah ditemukan dengan menggunakan simbol. Siswa juga melakukan peninjauan kembali untuk memastikan bahwa temuannya merupakan hasil yang benar.

Pada aktivitas berpikir dinamis, siswa memberikan cara/alternatif lain dalam menentukan pemecahan masalah dengan menggunakan gambar.

Pada aktivitas pemodelan, siswa membuat sebuah model matematika dalam bentuk persamaan yang mengaitkan informasi dari soal dengan hasil pemecahan masalah yang diperoleh sebelumnya sebagai representasi situasi yang baru.

Pada aktivitas berpikir analitis, siswa, siswa menyelesaiakan persamaan yang telah dibuat sebelumnya secara bertahap untuk menentukan nilai dari variabel sebagai hasil akhir pemecahan masalah. Dalam hal ini, siswa menggunakan operasi terbalik (strategi bekerja mundur) yang merupakan contoh khas berpikir analitis sehingga diperoleh hasil pemecahan masalah dengan benar.

Pada aktivitas organisasi, siswa menyusun informasi penting yang diperoleh dari masalah dalam bentuk tabel untuk menentukan pemecahan masalah.

Profil Berpikir Aljabar Siswa SMP dengan Kemampuan Matematika Rendah dalam Memecahkan Masalah Matematika Kontekstual

Pada aktivitas generalisasi, langkah pertama yang dilakukan siswa dalam memecahkan masalah, yaitu mengidentifikasi hubungan antar objek dengan cara mendaftar dalam tabel dan menemukan pola dari sekumpulan objek tersebut, kemudian menyebutkan pola yang telah ditemukan. Selanjutnya, siswa menggunakan pola yang telah ditemukan untuk menentukan suku berikutnya. Selain itu, siswa juga mengidentifikasi hubungan antar objek dengan menggunakan gambar dan menemukan pola dari sekumpulan objek tersebut, kemudian menggunakan pola yang telah ditemukan untuk menentukan suku berikutnya.

Pada aktivitas berpikir dinamis, siswa memberikan cara/alternatif lain dalam menentukan pemecahan masalah dengan menggunakan gambar.

Pada aktivitas organisasi, siswa menyusun informasi penting yang diperoleh dari masalah dalam bentuk tabel untuk menentukan pemecahan masalah.

Sementara aktivitas abstraksi tidak muncul pada siswa dengan kemampuan matematika rendah dalam memecahkan masalah, karena siswa tidak dapat memahami dan menjelaskan makna penggunaan simbol sebagai representasi dari hasil generalisasi. Hal ini mengakibatkan aktivitas pemodelan dan berpikir analitis juga tidak muncul.

Saran

Berdasarkan hasil penelitian yang diperoleh, maka peneliti memberikan saran sebagai berikut.

1. Pada penelitian ini dapat diketahui bahwa berpikir aljabar siswa dalam memecahkan masalah matematika berbeda-beda berdasarkan kemampuan matematika yang dimiliki, terutama siswa dengan kemampuan matematika rendah masih belum mampu memahami makna simbol sebagai representasi variabel yang belum diketahui nilainya, pada penyelesaian masalah terlihat siswa mengalami kesulitan, sehingga tidak diperoleh penyelesaian masalah dengan benar, dan aktivitas berpikir aljabar tidak dapat muncul secara keseluruhan. Oleh karena itu sebaiknya guru lebih memperhatian tingkat kemampuan matematika siswa dalam pengusaan 
konsep aljabar dan melatih siswa dalam memecahkan masalah matematika yang berkaitan dengan aljabar, terutama pada siswa dengan kemampuan matematika rendah.

2. Bagi peneliti lain yang akan melakukan penelitian menggunakan wawancara, hendaknya menyusun pedoman wawancara secara lengkap dan rinci agar hasil informasi yang diperoleh lebih lengkap dan mendalam.

\section{DAFTAR PUSTAKA}

Anggo, M. 2011. Pemecahan Masalah Matematika Kontekstual Untuk Meningkatkan Kemampuan Metakognisi Siswa. Edumatica Volume 01 Nomor 02, ISSN: 2088-2157 Page 35. Kendari: Universitas Haluoleo.

Bednarz, N., et al. 1992. "Arithmetical and Algebraic Thinking in Problem-Solving." In Proceedings of the $16^{\text {th }}$ Conference of the International Group for the Psychology of Mathematics Education (PME-16), (Online),

(http://www.laurentian.ca/NR/rdonlyres/92600BFICA50-4B00-9473B94476ADE3FA/0/arithmetical algebraic thinking.p df, diakses 20 Maret 2018).

Febriansyah, R. 2014. Analisis Kesulitan Belajar Siswa SMA dalam Memahami Materi Persamaan Linear Dua Variabel di Kelas X SMA. Pontianak: UNTAN.

Isroil, A., Budayasa, I. K., dan Masriyah. 2017. "Profil Berpikir Siswa SMP dalam Menyelesaikan Masalah
Matematika Ditinjau dari Kemampuan Matematika”. Jurnal Review Pembelajaran Matematika. Vol. 2, No. 2, Hal. 93-105.

Kementrian Pendidikan dan Kebudayaan. 2017. Kompetensi Inti dan Kompetensi Dasar Matematika SMP/MTs. Jakarta: Kementrian Pendidikan dan Kebudayaan.

Lew, H. C. 2004. "Developing Algebraic Thinking in Early Grades: Case Study of Korean Elementary School Mathematics". The Mathematics Educator. Vol. 8, No. 1, pp 88-106.

Lingga, A. dan Sari, W. 2013. "Pengaruh Kemampuan Berpikir Aljabar Terhdap Kemampuan Pemecahan Masalah Matematika". Eduma: Mathematics Education Learning and Teaching, (Online), (https://www.neliti.com/publications/56321/pengaruh -kemampuan-berpikir-aljabar-terhadap-kemampuanpemecahan-masalah-matemat, diakses 13 Desember 2018).

Maulidiah, N. 2016. Profil Berpikir Aljabar Siswa SMP dalam Pemecahan Masalah Matematika Ditinjau dari Kemampuan Matematika. Skripsi tidak diterbitkan. Surabaya: Universitas Negeri Surabaya.

Rivera, F. D. 2006. "Changing the Face of Arithmetic: Teaching Children Algebra". In Teaching Children Mathematics, Vol. 12, No. 6.

Suharnan. 2005. Psikologi Kognitif. Surabaya: Srikandi.

Walle, J. A. 2008. Matematika Sekolah Dasar dan Menengah Pengembangan Pengajaran. Virginia Commonwealth University : Erlangga Jakarta. 